\title{
PENGEMBANGAN MOTIF BATIK KANAKA UNTUK SERAGAM PPI ISHIKAWA JEPANG
}

\author{
Hafiza Aprilia' \\ (Jurusan Kriya, Fakultas Industri Kreatif, Universitas Telkom, apriliahafiza@student.telkomuniversity.ac.id, 082217798600) \\ Morinta Rosandini ${ }^{2}$ \\ (Jurusan Kriya, Fakultas Industri Kreatif, Universitas Telkom, morintarosandini@telkomuniversity.ac.id, 082116610768)
}

\begin{abstract}
PPI Ishikawa, Japan has a jacket uniform, but this uniform doesn't have a strong Indonesian visual identity yet in it. The Kanaka Batik which was the winner in the batik design contest held by PPI Ishikawa, Japan to be made a uniform hasn't been realized due to the difficulty of producing the batik. Therefore the purpose of this design is to design the PPI Ishikawa, Japanese uniform by applying the Kanaka Batik motif that has been developed by applying the digital printing and embroidery techniques. The stage of the design method is in the form of problem analysis and problem solving strategies. Then the result of this are three designs of developing Kanaka Batik motifs on a fabric measuring $90 \times 100 \mathrm{~cm}$ and one sketch of a uniform design of a jacket with the development of Kanaka Batik motifs in it. Through this paper it's hoped that it can add references for the readers.
\end{abstract}

Keywords: Kanaka batik, motif, PPI Ishikawa Japan, uniform

\section{ABSTRAK}

PPI Ishikawa Jepang memiliki seragam berupa jaket, namun seragam ini belum memiliki identitas visual Indonesia yang kuat di dalamnya. Adapun Batik Kanaka yang menjadi pemenang dalam sayembara desain batik yang diadakan oleh PPI Ishikawa Jepang untuk dijadikan seragam belum direalisasikan karena kesulitan memproduksi batik tersebut. Maka dari itu tujuan perancangan ini ialah untuk merancang seragam PPI Ishikawa Jepang dengan mengaplikasikan motif Batik Kanaka yang telah dikembangkan dengan penerapan teknik digital printing dan bordir. Tahapan metode perancangan ini berupa analisis permasalahan dan strategi pemecahan masalah. Kemudian hasilnya adalah tiga desain pengembangan motif Batik Kanaka pada kain berukuran $90 \times 100 \mathrm{~cm}$ dan satu sketsa desain seragam jaket dengan pengembangan motif Batik Kanaka di dalamnya. Melalui karya tulis ini diharapkan dapat menambah referensi bagi para pembaca.

Kata Kunci: batik Kanaka, motif, PPI Ishikawa Jepang, seragam

\section{PENDAHULUAN}

Pemakaian seragam pada suatu organisasi merupakan sesuatu yang tidak asing lagi saat ini. Seragam yang dikenakan pada suatu organisasi tersebut berfungsi sebagai identitas yang membedakan antara anggota organisasi satu dengan organisasi lainnya. Menurut Michael dalam Wowor (2010), seragam adalah pakaian yang dikenakan anggota suatu organisasi ketika berpartisipasi pada kegiatan organisasi tersebut dan dapat memberikan hal yang positif bagi pemakainya. 
Perkembangan seragam tidak hanya dalam bentuk formal, seperti kemeja, namun berdasarkan hasil observasi, saat ini terdapat seragam informal seperti t-shirt dan outer. Dalam seragam yang menjadi identitas tentunya terdapat tanda atau ciri khas dari organisasi tersebut.

Salah satu contoh seragam berupa jaket dikenakan oleh suatu organisasi pelajar Indonesia yang berada di wilayah Jepang, yaitu Perhimpunan Pelajar Indonesia (PPI) Ishikawa, Jepang. Berdasarkan hasil observasi, seragam tersebut memiliki ciri khas berupa logo PPI Ishikawa Jepang, bendera Indonesia, dan tulisan dalam bentuk huruf kanji. Seragam tersebut dikenakan saat melakukan kegiatan Hanami, yaitu kegiatan rutin tahunan di musim semi melihat bunga Sakura mekar dan piknik bersama yang dilakukan oleh anggota PPI Ishikawa, Jepang. Menurut Ciptandi (2020) sebuah motif dalam kain atau pakaian dapat memberikan ciri khas di dalamnya, sehingga dapat diketahui dari mana asal kain atau pakaian tersebut. Oleh karena itu dalam hal ini ciri khas pada seragam dapat dijadikan sebagai identitas untuk mengenali seseorang yang memakainya sebagai anggota yang berada pada suatu organisasi tersebut (Wowor, 2010).

Di Indonesia, batik merupakan salah satu identitas dalam bentuk budaya (Iskandar \& Kustiyah, 2017). Hal tersebut telah diresmikan sejak tahun 2009 oleh UNESCO (Utami et.al, 2018). Sebagai upaya menanamkam pentingnya batik sebagai bagian dari identitas bangsa dan mempromosikan batik di Jepang, maka PPI Ishikawa Jepang mengadakan sayembara desain batik yang diadakan pada tahun 2017. Hasil dari sayembara ini dimenangkan oleh Batik Kanaka karya dari Morinta Rosandini (Rosandini, 2017).

Berdasarkan hasil wawancara dengan Imam Tahyudin selaku Ketua Komsat PPI Ishikawa, Jepang tahun 2019 dan Ibu Maharani sebagai salah satu anggota PPI Ishikawa Jepang, sayembara desain batik tersebut merupakan ide awal untuk membuat seragam.
PPI Ishikawa Jepang sendiri juga belum memiliki identitas berupa seragam dengan unsur visual Indonesia yang kuat di dalamnya.

Pada saat ini batik Kanaka belum direalisasikan sebagai seragam PPI Ishikawa Jepang karena adanya kesulitan untuk memproduksi batik tersebut dan berdasarkan hasil wawancara dengan Imam Tahyudin, Batik Kanaka merupakan milik PPI Ishikawa Jepang dan diperbolehkan untuk dikembangkan kembali. Oleh karena itu, terdapat peluang untuk mengembangkan visual motif Batik Kanaka, sehingga mendapatkan inovasi motif baru yang selanjutnya diterapkan dengan teknik surface textile design tertentu untuk menambahkan unsur estetika pada permukaan kain, lalu diaplikasikan pada produk berupa seragam untuk PPI Ishikawa, Jepang.

\section{PPI Ishikawa Jepang}

Menurut website resminya (www.ishikawa.ppijepang.org) PPI Ishikawa Jepang merupakan salah satu perhimpunan pelajar Indonesia (PPI) di wilayah Jepang yang menginduk pada organisasi PPI Jepang. PPI Ishikawa, Jepang ini menjadi suatu wadah bagi mahasiswa Indonesia untuk berbagi ilmu, pengalaman, serta kepedulian terhadap permasalahan dan isu.

Adapun kegiatan rutin tahunan PPI Ishikawa Jepang yang menjadi upaya untuk mempererat kekeluargaan seluruh anggota ialah Welcoming Party, Farewell Party, Hanami, Sharing and Discussion, dan PORDA.

\section{Batik Kanaka}

Menurut Indreswari (2016) akulturasi juga terjadi pada batik, serta motif dalam batik pada saat ini perkembangannya sangat beragam (Rosandini et.al, 2019). Salah satu contohnya yaitu Batik Kanaka karya dari Morinta Rosandini yang menjadi pemenang dari sayembara desain batik yang diadakan oleh PPI Ishikawa Jepang di tahun 2017. 
Motifnya terdiri atas perpaduan budaya Indonesia dan Jepang, yaitu Batik Truntum, bunga Sakura, burung bangau, dan arsitektural Kumano Nachi Taisha (Rosandini, 2017).

Filosofi dari batik ini adalah menjadi harapan bagi siapa pun yang memakainya, menjadi simbol kebaikan, rasa peduli, dan sejauh apapun melangkah rasa cinta terhadap tanah air tetap tertanam dalam hati sanubari. Batik ini dibuat dengan teknik batik tulis melalui proses canting-celup-lorod dengan komposisi half drop repetition (Rosandini, 2017).

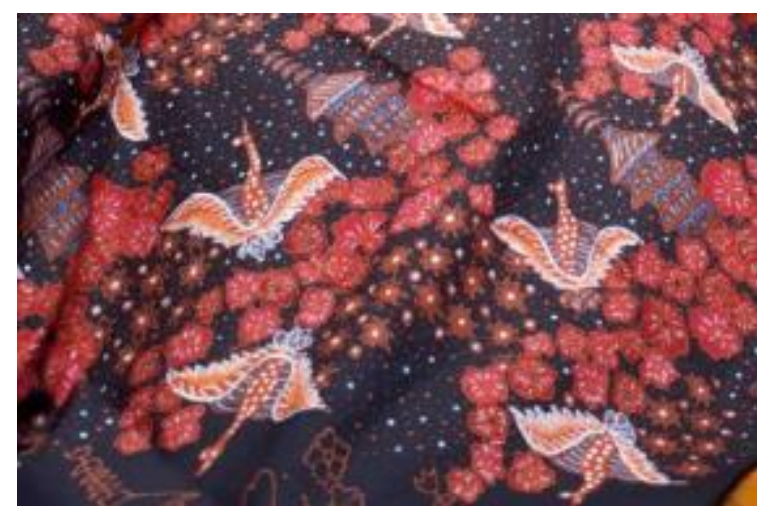

Gambar 1. Batik Kanaka

(Sumber: Rosandini, 2017)

\section{METODE}

Untuk mencapai tujuan perancangan, tahapan metode perancangan yang dilalui ialah analisis permasalahan dan strategi pemecahan masalah.

\section{a. Analisis Permasalahan}

Berdasarkan latar belakang, terdapat tiga hal yang menjadi permasalahan dalam perancangan desain seragam ini, yang pertama ialah pengembangan bentuk visual dari motif Batik Kanaka untuk diterapkan pada desain seragam PPI Ishikawa Jepang. Kedua, perancangan desain seragam sebagai identitas yang tepat untuk PPI Ishikawa, Jepang. Ketiga, penerapan teknik surface textile design yang tepat untuk seragam tersebut.

\section{b. Strategi Pemecahan Masalah}

Untuk mengatasi permasalahan yang telah disebutkan di atas, hal yang perlu dilakukan pertama kali adalah dengan mengumpulkan data dari hasil wawancara, observasi dan studi analisa motif. Data yang telah terkumpul digunakan untuk menjadi dasar dari penentuan pengembangan bentuk visual motif, desain seragam dan teknik yang akan digunakan. Lalu yang kedua ialah dari pengembangan bentuk visual motif batik Kanaka dibuat dengan memperhatikan karakter batik Kanaka, dengan pertimbangan komposisi dan warna. Ketiga, perancangan desain seragam dibuat dalam bentuk jaket dengan pengembangan motif batik Kanaka di bagian belakang. Lalu yang keempat yaitu penerapan motif menggunakan teknik surface textile design berupa digital printing dan bordir.

\section{PEMBAHASAN}

\section{Hasil Uji Coba}

Hasil uji coba ini terdiri uji coba pengembangan bentuk visual motif dan penerapan teknik pada material kain. Uji coba pada bentuk visual motif dilakukan pada unsurunsur motif batik Kanaka, yaitu batik Truntum, bunga Sakura, burung bangau dan arsitektural Kumano Nachi Taisha.

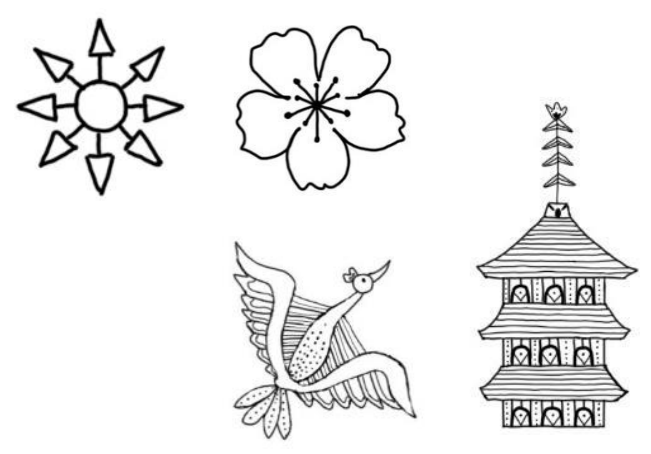

Gambar 2. Pengembangan Motif Batik Kanaka (Sumber: Hafiza Aprilia)

Setelah itu penulis melakukan uji coba pada susunan komposisi single motif dari 
unsur-unsur motif yang telah dibuat dan melakukan pewarnaan. Terdapat tiga motif dengan peletakan unsur-unsur motif yang berbeda. Kemudian pemilihan warna dilakukan dengan pertimbangan warna yang sesuai dengan konsep serta warna yang cocok untuk unisex karena anggota PPI Ishikawa, Jepang terdiri dari laki-laki dan perempuan.

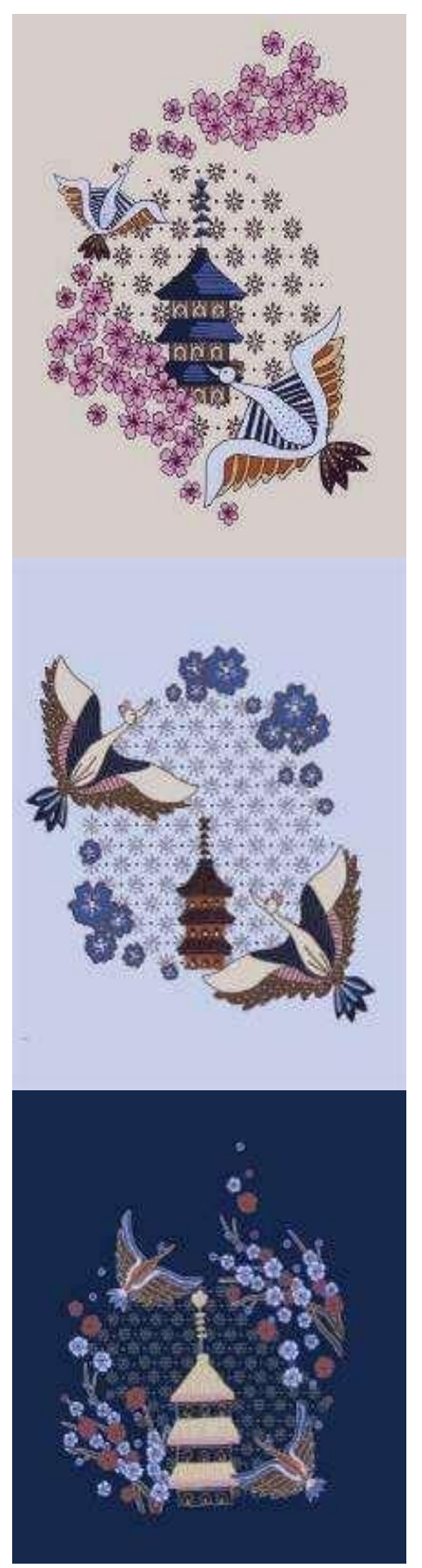

Gambar 4. Hasil Penerapan Teknik Digital Printing dan Bordir Pada Kain (Sumber: Hafiza Aprilia)

\section{Konsep Perancangan}

Konsep perancangan produk ini mengangkat tema "Bond in Unity" yang berarti ikatan dalam persatuan. Hal ini terinspirasi dari ikatan yang terjalin pada anggota PPI Ishikawa Jepang, yaitu persatuan dan kekeluargaan. Persatuan digambarkan dengan warna biru yang memiliki makna serupa sedangkan kekeluargaan digambarkan dengan penggunaan warna yang lembut seperti merah muda yang menggambarkan kasih sayang keluarga, warna jingga dengan makna kehangatan dan warna cokelat yang diambil dari Batik Kanaka.

Penggayaan motifnya terinspirasi dari Jaket Sukajan yang memiliki ciri khas bentuk motif yang besar dengan komposisi single motif yang dibuat dengan teknik bordir, namun tetap mempertahankan ciri khas Batik Kanaka yang memiliki karakter yang dibuat dengan canthing dan banyak menggunakan unsur titik dan garis. Adapun judul koleksi perancangan produk ini ialah Janka yang merupakan gabungan dari kata jan atau janpaa yang berasal dari bahasa Jepang yang berarti jaket dan Kanaka.

Hasil perancangan ini menghasilkan tiga motif pengembangan Batik Kanaka dengan komposisi single motif yang diterapkan pada kain Taslan berukuran $90 \mathrm{x}$ $100 \mathrm{~cm}$ dengan teknik digital printing dan bordir dan salah satu motifnya dibuat ke dalam bentuk desain seragam jaket. Desain pengembangan motif Batik Kanaka ini dapat diaplikasikan pada desain seragam jaket untuk anggota PPI Ishikawa Jepang, dalam bentuk unisex.

\section{Visualisasi Desain}

Sebagai satu koleksi perancangan untuk desain seragam, tiga desain pengembangan motif batik Kanaka ini memiliki kemiripan dari segi siluet yang tampak sedikit mirip, yaitu menyerupai bentuk lingkaran. Bentuk lingkaran sendiri 
memiliki makna hubungan dan persatuan yang mana sesuai dengan konsep perancangan.

Pada desain pertama dengan judul Janka 1.0 motif dibuat dengan komposisi single motif berukuran $33 \times 46 \mathrm{~cm}$ pada kain Taslan berukuran $90 \times 100 \mathrm{~cm}$. Motif ini diterapkan pada kain dengan teknik digital printing dan bordir penuh hanya di bagian dua burung bangau. Motif ini memiliki kombinasi warna gelap dan terang dengan warna latar cokelat terang serta warna merah muda dan biru sebagai kontras.

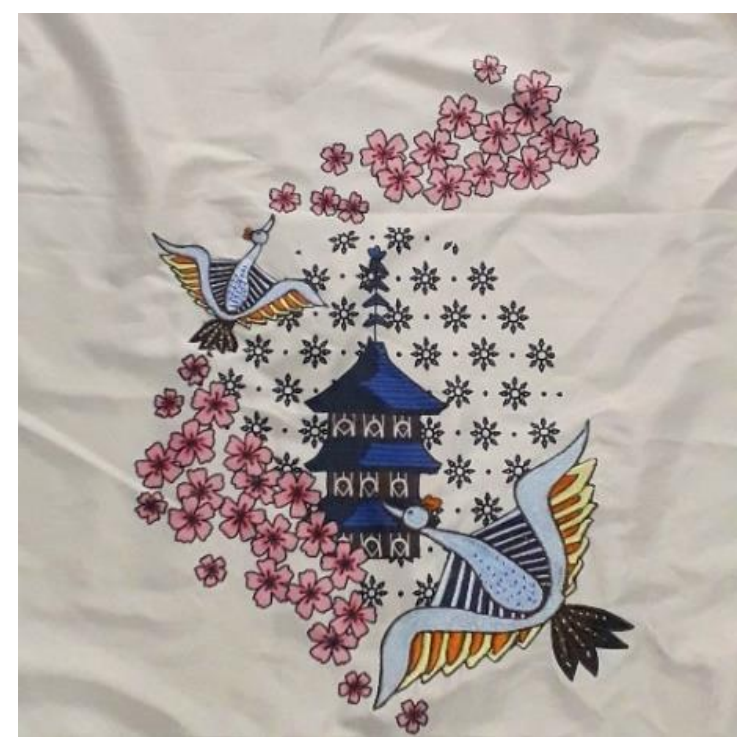

Gambar 5. Janka 1.0

(Sumber: Hafiza Aprilia)

Kemudian pada desain kedua dengan judul Janka 2.0, motif dengan komposisi single motif ini dibuat dengan ukuran $36 \times 36 \mathrm{~cm}$ dalam kain berukuran $90 \times 100 \mathrm{~cm}$. Motif ini diterapkan pada kain Taslan dengan teknik digital printing dan bordir penuh pada dua burung bangau. Warna yang digunakan pada motif ini terdiri dari warna gelap dan terang, menggunakan warna biru terang sebagai warna latar, lalu warna jingga dan cokelat untuk memberikan nuansa kontras.

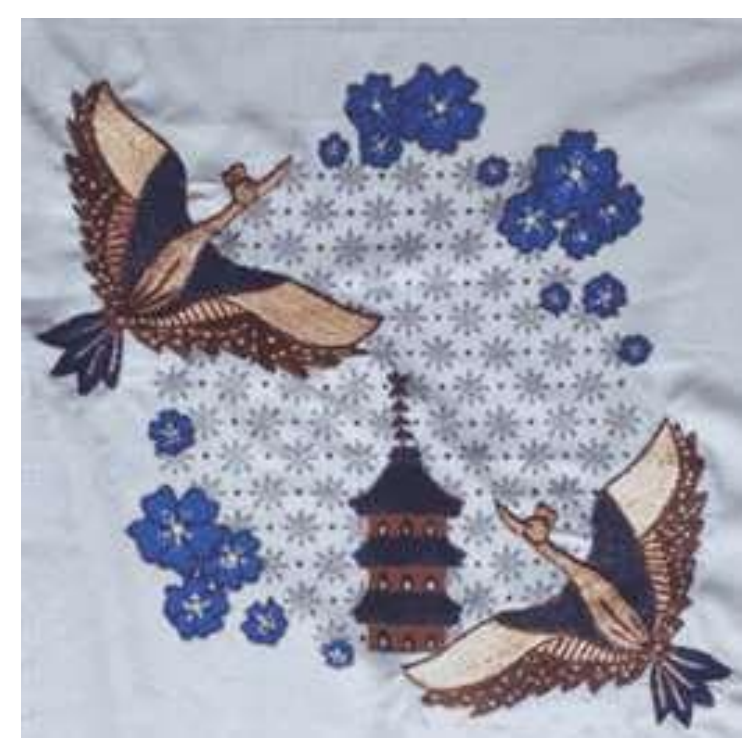

Gambar 6. Janka 2.0

(Sumber: Hafiza Aprilia)

Desain selanjutnya berjudul Janka 3.0, motif dibuat dengan komposisi single motif dalam ukuran $35 \times 46 \mathrm{~cm}$ dalam kain Taslan berukuran $90 \times 100 \mathrm{~cm}$. Penerapan motif pada kain dilakukan dengan teknik digital printing dan bordir yang dilakukan pada arsitektural Kumano Nachi Taisha. Warna latar motif ini menggunakan warna biru gelap, disertai kombinasi warna gelap terang di dalamnya dengan warna jingga dan cokelat terang sebagai kontras.

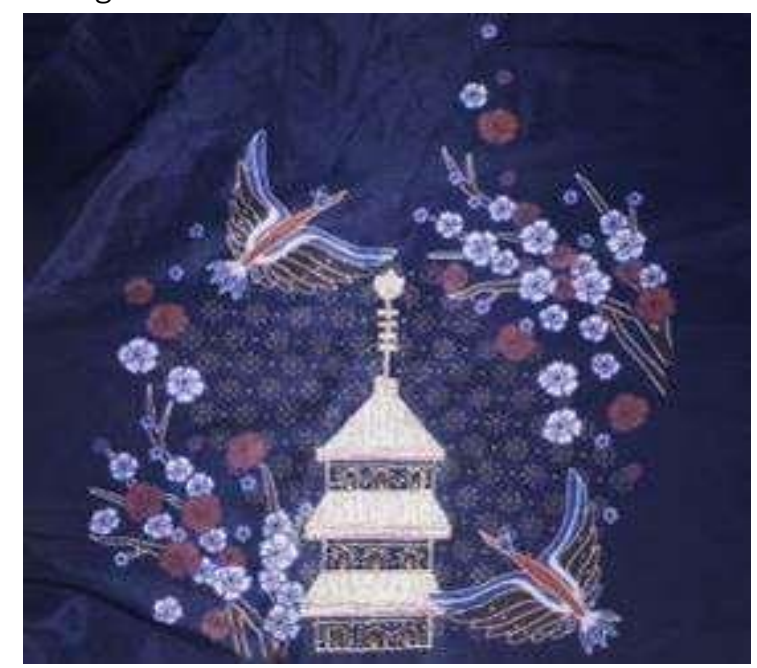

Gambar 7. Janka 3.0

(Sumber: Hafiza Aprilia)

Salah satu dari tiga motif ini, yaitu desain dengan judul Janka 1.0 dibuat dalam 
sketsa desain seragam dalam bentuk jaket. Desain seragam berupa jaket ini mengadaptasi dari jaket baseball, penempatan motif berada di bagian belakang terinspirasi dari ciri khas Jaket Sukajan yang identik dengan motif di bagian belakang jaket dengan ukuran motif yang besar.

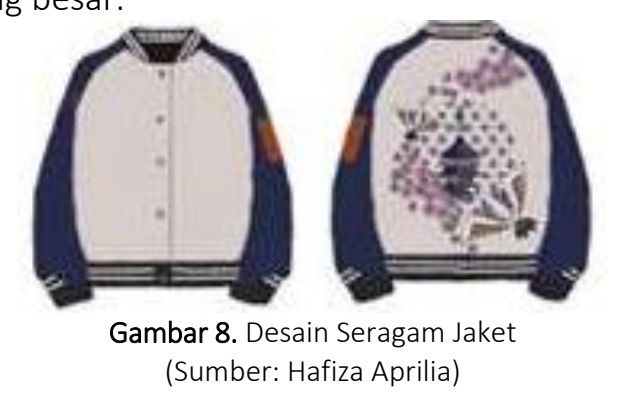

\section{PENUTUP}

Berdasarkan dari analisis
permasalahan dapat disimpulkan bahwa mengenai pengembangan motif batik Kanaka yang dilakukan menghasilkan inovasi motif baru namun tetap mempertahankan karakter motif batik yang dibuat dengan canthing, banyak menggunakan unsur titik dan garis, menggunakan komposisi single motif dan pewarnaan yang sesuai dengan konsep. Seragam jaket yang dikenakan pada saat melakukan kegiatan Hanami tampak belum memiliki unsur visual Indonesia yang kuat di dalamnya. Maka dari itu perancangan desain seragam dibuat dalam bentuk seragam jaket dengan pengembangan motif batik Kanaka di dalamnya, sehingga menjadi ciri khas identitas anggota dari PPI Ishikawa Jepang. Penerapan teknik digital printing dan bordir digunakan untuk mengatasi kesulitan memproduksi Batik Kanaka yang dibuat dengan batik tulis. Teknik digital printing dipilih karena diperuntukkan untuk produksi massal dan prosesnya relatif cepat, kemudian teknik bordir yang terinspirasi dari Jaket Sukajan, diterapkan pada beberapa bagian motif untuk menambah unsur estetika dan tekstur. Selain itu untuk seragam tidak hanya terbatas pada jenis warna dan bentuk yang sama atau mirip satu sama lain, dalam karya tulis ini seragam untuk PPI Ishikawa
Jepang dibuat satu koleksi rancangan seragam yang terdapat tiga jenis perbedaan warna latar dan susunan komposisi, sehingga setiap anggota dapat memilih warna seragam yang diinginkan. Walaupun terdapat sedikit perbedaan tetap ada ciri khas yang sama, yaitu pengembangan motif Batik Kanaka.

\section{DAFTAR PUSTAKA}

Ciptandi, F. (2020). Innovation of motif design for traditional batik craftsmen. In Understanding Digital

Indreswari, A. G. (2016). Batik Topo Bantul: Konsisten dalam Pembuatan Kain Batik Tulis dan Cap. Corak: Jurnal Seni Kriya, 5(1), 1.

Iskandar \& Kustiyah, E. (2017). Batik Sebagai Identitas Kultural Bangsa Indonesia di Era Globalisasi. Jurnal GEMA, 30(52).

Rosandini, M., \& Syafrudin, I. (2017). Pengolahan Motif Batik Perpaduan Unsur Tradisi Jawa dan Jepang. Jurnal Rupa, 2(2), 138.

Rosandini, M., Rosmawati, R., Larassati, K., \& Falabiba, Q. M. (2019). Re-designing Batik Mbako Motif Pattern. In $6^{\text {th }}$ Bandung Creative Movement 2019. Telkom University.

Utami, A. N., Setyawan, \& Dartono, F. A. (2018). Pengembangan Desain Batik Makassar dengan Sumber Ide Kapal Pinisi. Corak: Jurnal Seni Kriya, 7(2), 102.

Wowor, W. (2010). Pengaruh Seragam Karyawan Terhadap Sikap Kerja Karyawan Pada Industri Perhotelan (Studi Kasus Pada Hotel XYZ Jakarta. Jurnal Hospitour, 1(1).

\section{Website/laman:}

PPIJ Ishikawa. About. Diakses pada 17 November 2019, dari https://ishikawa.ppijepang.org/about 